\title{
The Cretaceous age of the Vinegar Hill silica sand deposit, southern New Brunswick: evidence from palynology and paleobotany
}

\author{
Howard J. Falcon-Lang, ${ }^{1}$ Robert A. Fensome, ${ }^{2 *}$ and D.V. Venugopal ${ }^{3}$ \\ 1. Department of Earth Sciences, Dalhousie University, Halifax, Nova Scotia, B3H 3J5 \\ (Current Address: Department of Earth Sciences, University of Bristol, Bristol BS8 1RJ, UK) \\ 2. Natural Resources Canada, Geological Survey of Canada (Atlantic), \\ Bedford Institute of Oceanography, P.O. Box 1006, Dartmouth, Nova Scotia B2Y 4A2, Canada \\ 3. New Brunswick Department of Natural Resources and Energy, Geological Surveys Branch, P.O. Box 6001, Fredericton, \\ New Brunswick E3B 5H1; current address 11 Baxter Court, Fredericton, New Brunswick E3B 6M2, Canada \\ ${ }^{*}$ Corresponding author
}

Date received:November 5, 2002 I Date accepted:June 30, 2003

\begin{abstract}
A small outcrop of quartz (silica) sand has been recognized at Vinegar Hill, near Cassidy Lake south of Sussex, New Brunswick, since the 1980s and extracted for commercial purposes. The deposit overlies Carboniferous rocks and underlies glacial deposits, and its setting is very similar to comparable, confirmed Cretaceous deposits in Nova Scotia. The age of the Vinegar Hill deposit, which appears to be of fluvial origin, has been unconfirmed until the present study. In this study, a general Mesozoic-early Tertiary age is indicated by the identity of a fossil araucarian wood specimen that occurs within the sand, and palynomorphs suggest a late Early Cretaceous, probably Albian, age. The absence of true growth rings in the wood implies a humid subtropical climate characterized by high temperatures, a conclusion consistent with a Cretaceous age because such climates are predicted for that age in the region by global paleoclimate reconstructions. The Vinegar Hill deposit represents the only known outcrop of Cretaceous strata in New Brunswick, but given its economic and scientific interest, a search for similar basins in the province would be worthwhile.
\end{abstract}

\section{RÉSUMÉ}

Un petit affleurement de sable quartzeux (silice) a été repéré sur la colline Vinegar, près du lac Cassidy, au sud de Sussex, Nouveau-Brunswick, au cours des années 80 et il a fait l'objet d'extraction à des fins commerciales. Le gite recouvre des roches du Carbonifère et se trouve sous des dépôts glaciaires, dans un cadre semblable aux gites crétacés confirmés comparables de la Nouvelle-Écosse. L'âge du gîte de la colline Vinegar, qui semble d'origine fluviatile, n'avait pas été confirmé avant la présente étude. L'étude le situe d'une façon générale au Mésozoïque-Tertiaire inférieur en s'appuyant sur l'identité d'un spécimen de bois araucarien fossile présent à l'intérieur du sable; les palynomorphes laissent supposer qu'il remonterait à la fin du Crétacé inférieur, probablement l'Albien. L'absence de cernes réels dans le bois permet de supposer un climat subtropical humide caractérisé par des températures élevées, une conclusion qui est compatible avec un âge le situant au Crétacé parce qu'on peut déterminer la présence de tels climats dans la région à cette époque au moyen de reconstructions paléoclimatiques planétaires. Le gîte de la colline Vinegar représente le seul affleurement connu de strates du Crétacé au Nouveau-Brunswick, mais vu son intérêt économique et scientifique, il serait intéressant de rechercher des bassins semblables dans la province.

\section{INTRODUCTION}

Outcrops of Cretaceous siliciclastic and lignitic rock occur sporadically but widely in Nova Scotia (Stea and Pullan 2001; Fig. 1), their general age having been proven on the basis of palynology (Stevenson 1959). The Nova Scotia deposits are usually found in faulted basins overlying a range of Carboniferous formations, or in sinkholes within Windsor Group evaporites. Their most distinctive lithological components are silica sands and kaolin clays, both of which have been extracted commercially.
A small deposit of predominantly silica sand is located at Campbell Settlement, $4 \mathrm{~km}$ northeast of Cassidy Lake and about 10-15 km south of Sussex, southern New Brunswick (Figs. 1,2). It was first reported by Lockhart $(1983,1984,1988)$ and has since become the subject of commercial extraction by the Atlantic Silica company. In some earlier reports (Venugopal 1994, 1999) this material was referred to as the Cassidy Lake deposit, but was termed the "Vinegar Hill Formation" on the 1:500 000 scale geological map of New Brunswick (New Brunswick Department of Natural Resources and Energy 2000). We refer to it here as the Vinegar Hill deposit. 


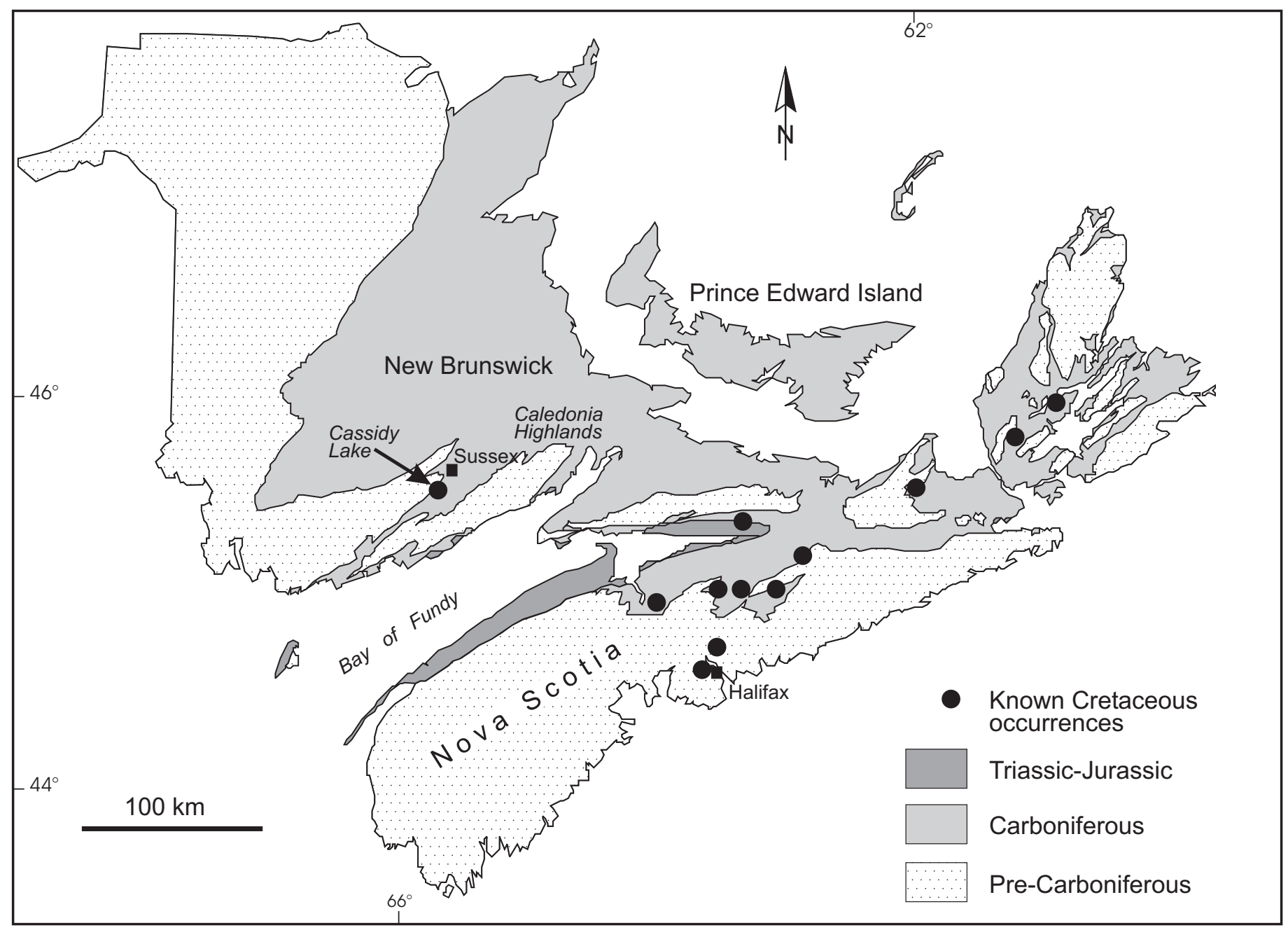

Fig. 1 Cretaceous occurrences and general geology of the Maritime Provinces of Canada. This map is based in part on an original in Stea and Pullan (2001). Additional occurrences have been added on the basis of unpublished palynological analyses by one of us (RAF) and E.H. Davies.

This New Brunswick deposit, because of its similarity of geological setting and lithological content to some Nova Scotia deposits, has been thought to be of Cretaceous age (see, for example, Atlantic Geoscience Society 2001), but this age has not previously been confirmed by direct evidence. Here we present palynological, paleobotanical and paleoclimatic evidence confirming that the Vinegar Hill deposit is of Cretaceous, probably Albian, age. It is thus the first known occurrence of late Mesozoic rocks in the province, the next oldest rocks being Early Jurassic lava flows on Grand Manan Island and dykes of that age in both southern and northern New Brunswick; the next youngest rocks are widespread Quaternary deposits. This is thus a similar stratigraphic succession to that found in mainland Nova Scotia (Stea and Pullan 2001).

\section{GEOLOGY}

The local geology of the Vinegar Hill deposit is shown in Figure 2 (McLeod et al. 1994; St. Peter 1995). The deposit occurs in a down-faulted block on the south side of the Clover
Hill Fault, a major structural break in the immediate vicinity of Campbell Settlement (Venugopal 1994). The fault separates the rocks of the Memramcook Formation (Horton Group) of latest Devonian-Tournasian age from the younger, late Viséan to early Namurian, clastic sedimentary rocks of the Mabou Group (Belt 1965; St. Peter 2001). The putative Cretaceous sediments overlie rocks of the Mabou Group.

Silica sand forms the major constituent of the Cretaceous deposit, but clay is also important (Venugopal 1999). Clay occurs throughout the matrix, where it is admixed with silica flour, and as thin (a few millimetres to $60 \mathrm{~cm}$ ), horizontal to sub-horizontal, lenticular, poorly stratified horizons interbedded with the silica sand. Locally the layers display crude graded bedding, fining up with discontinuous cross stratification. The grain size distribution of the quartz is generally bimodal, varying from cobbles to pea-sized pebbles in the coarser fraction and gravel to fine flour in the finer fraction. However, locally the quartz grain size displays gradual transition from cobble to flour. The pebbles are sub-angular to sub-rounded and poorly sorted. They are generally coated with rusty sulphidic, hematitic and manganese staining. In part of the sequence, large-scale 

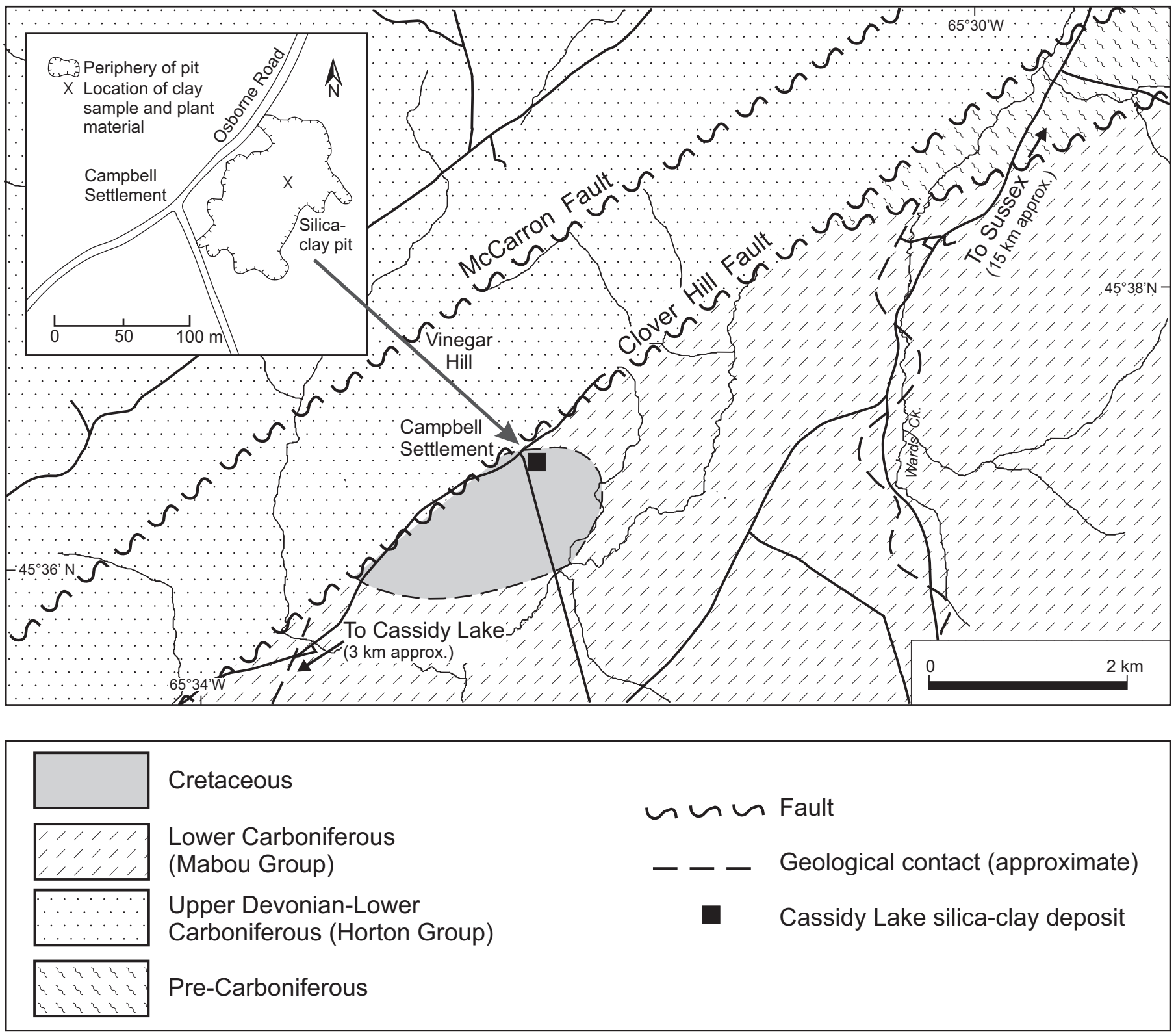

Fig. 2 Geological setting and location of the New Brunswick Cretaceous deposit. The inset shows the outline and precise location of the Vinegar Hill pit. Geological map based on an original by St. Peter (1995).

tabular cross beds are present, suggestive of a braided fluvial setting.

A 1-15 m thick overburden of glacial till and soil, derived largely from Mabou rocks, lies above the Cretaceous deposit and is thickest in the centre of the area. The glacial till consists of a mixture of mostly grey, red and brown volcanic and sedimentary rocks, red silty gravel and minor red to brown clay. The pebbles in the coarser fraction are sub-angular to sub-rounded.

\section{METHODS AND SAMPLES}

The first sample (Geological Survey of Canada palynological processing number P37213) analyzed palynologically was collected by one of us (DVV) in 1999. It was obtained from the northeastern part of the pit (see Fig. 2). It is light- to mediumgrey, locally-black clay containing plant material. The plant material is medium to dark gray to grayish brown, and may represent the remnants of a tree trunk or branch $10-15 \mathrm{~cm}$ in diameter. The material displays partial charcoal appearance and has preserved woody texture. It yielded associated palynomorphs - presumably from sediment surrounding or infilling pores in the wood - as discussed below.

Two of us (RAF and DVV) collected a further 7 samples from the pit in September 2001. All samples were from thin clay or silt lenses within the sands, except for one sample from a block of lignite that was clearly part of a tree trunk, 30-40 $\mathrm{cm}$ in length. Its prostrate position in the sand suggests fluvial transport. All 7 samples were processed for palynology, but 
only the lignite sample (P37974) yielded palynomorphs. A portion of the lignite was forwarded to the other author (HFL) for analysis.

The palynology samples were processed using standard techniques based on those outlined in Barss and Williams (1973). The palynomorphs were stained using Bismarck Brown dye. Analysis was undertaken using Zeiss Axioplan 2 microscope, Natural Resources Canada number A042033, at the Bedford Institute of Oceanography, Dartmouth, Nova Scotia. The fossil wood (lignite) was examined using a Hitachi S-3200 Scanning Electron Microscope (SEM) at the National Research Council, Halifax, Nova Scotia.

\section{PALYNOLOGY}

The original sample (P37213) examined for palynology yielded very few palynomorphs, the only convincingly in-place spore being a specimen of Concavisporites toralis (Fig. 3d). (Full taxonomic names, with authorships, are provided in Appendix 1.) This is a smooth trilete fern spore, the laesurae enclosed within a continuous fold, or kyrtome. Although common in Cretaceous strata, the species is not restricted to that period, so it could not be considered age-diagnostic.

The lignite sample collected on the 2001 visit to the pit (P37974) yielded definitive, though sparse evidence for a Cretaceous age. This sample contained a single specimen of the schizaealean fern spore Cicatricosisporites sp. (Fig. 3 $\mathrm{a}-\mathrm{b})$ and several specimens of the bisaccate gymnosperm pollen Rugubivesiculites reductus (Fig. $3 \mathrm{f}-\mathrm{g}$ ). The genus Cicatricosisporites ranges from the Late Jurassic to the present day, but the form found in the Vinegar Hill material, although not identifiable to species level, resembles typical Cretaceous forms. The genus Rugubivesiculites is restricted to the Cretaceous and its base (first appearance datum) is used as a Late Albian marker in offshore eastern Canada (unpublished observations by G.L. Williams and R.A. Fensome). However, it has been found in earlier Cretaceous strata elsewhere (R.A. MacRae, personal communication, 2002). The slide also contained non-diagnostic bisaccate pollen other than Rugubivesiculites reductus.

A second slide was subsequently made from the first sample (P37213) and a single specimen of the hepatacacean spore, Zlivisporis sp. (Fig. 3c) was recovered. Species of the genus Zlivisporis (in many previous studies assigned to the genera Rouseisporites or Triporoletes - see Braman 2001 for a discussion) are characteristically (although not diagnostically) Cretaceous in age. The specimen appears to be of a previously undescribed species, possessing a distal reticulum with very heavy, beaded, double muri.

In the Nova Scotia onshore Cretaceous deposits, cysts of freshwater algae are common (see for example Eisnor, 2002). No distinctive algal cysts were encountered in the two palyniferous New Brunswick samples, although some nondescript bodies may represent algae or fungi (Fig. 3e). Neither marine palynomorphs nor angiosperm pollen grains were recognized.

\section{FOSSIL WOOD}

In hand specimen, the wood sample from which palynological sample P37974 is derived consists of a brown-coloured, lignitic wood fragment $11.7 \mathrm{~cm}$ in length. In cross-section the pronounced curvature of the specimen indicates that it was derived from close to the centre of an axis at least $6.8 \mathrm{~cm}$ in diameter. Examined with the SEM, anatomical features are clearly visible. In radial longitudinal section (RLS), 25-30 $\mu \mathrm{m}$ diameter tracheids exhibit uniseriate or biseriate, contiguous bordered pitting (borders: $15 \mu \mathrm{m}$ diameter, apertures: $7 \mu \mathrm{m}$ diameter; Fig. 4a). Uniseriate pits are oval, being squashed together, whereas biseriate pits are alternately arranged and circular (Fig. 4b). Cross-field regions possess 2-4 araucarioid pits per field (Fig. 4c-d). Axial parenchyma occurs sparsely. Spool-shaped resin plugs and pronounced checking are also very common locally (Fig. 4e). In tangential longitudinal section (TLS), rays are uniseriate and short (1-10 cells high), being composed of parenchyma, $16 \mu \mathrm{m}$ wide, $22 \mu \mathrm{m}$ high, and $90 \mu \mathrm{m}$ long. In transverse section (TS), rays are up to $1.5 \mathrm{~mm}$ long, and spaced 2-8 tracheids apart. True growth rings are entirely absent (Fig. 4f) but, rarely, weakly developed, diffuse "growth zones" may occur, spaced 2-3 mm apart ( $\mathrm{n}=23$ ).

Wood with these features is classified as Araucarioxylon, a very common Triassic-Recent form genus, which bears a close similarity to the woods of the extant conifer family Araucariaceae (Greguss 1972). Although more material must be collected before a confident species attribution can be made, the Vinegar Hill specimen is closely similar to Araucarioxylon pseudoparenchymatosum, a widespread species with an Early Cretaceous to Paleocene range (Falcon-Lang and Cantrill 2001). The absence of spiral thickening and the uniformity of "growth zone" width around the stem circumference suggest that the specimen derived from a vertically-orientated trunk. Applying the biomechanical relationship, determined by Niklas (1994), between trunk diameter and height, the slender araucarian trunk would have supported a tree at least 8 m high.

Araucarian conifers were globally widespread during the Mesozoic, reaching their peak in the Northern Hemisphere in Cretaceous times (Enright and Hill 1995). They became extinct in North America and Europe by the Eocene and today are restricted to a few isolated Southern Hemisphere sites (Enright and Hill 1995). The occurrence of araucarian wood therefore constrains the age of the Vinegar Hill deposit to the Mesozoicearly Tertiary interval. Should the specific identity of the wood be confirmed, the deposit's range would be further constrained to the Cretaceous-Paleocene. Wood data are thus consistent with the Cretaceous age determination based on palynological evidence, and places a minimum Eocene age constraint on the deposit. 


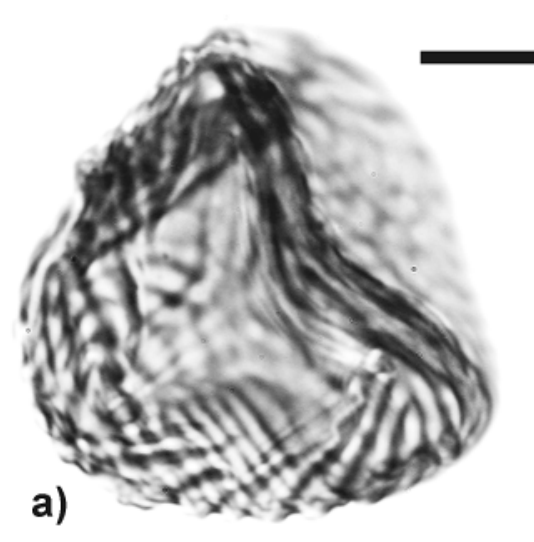

b)
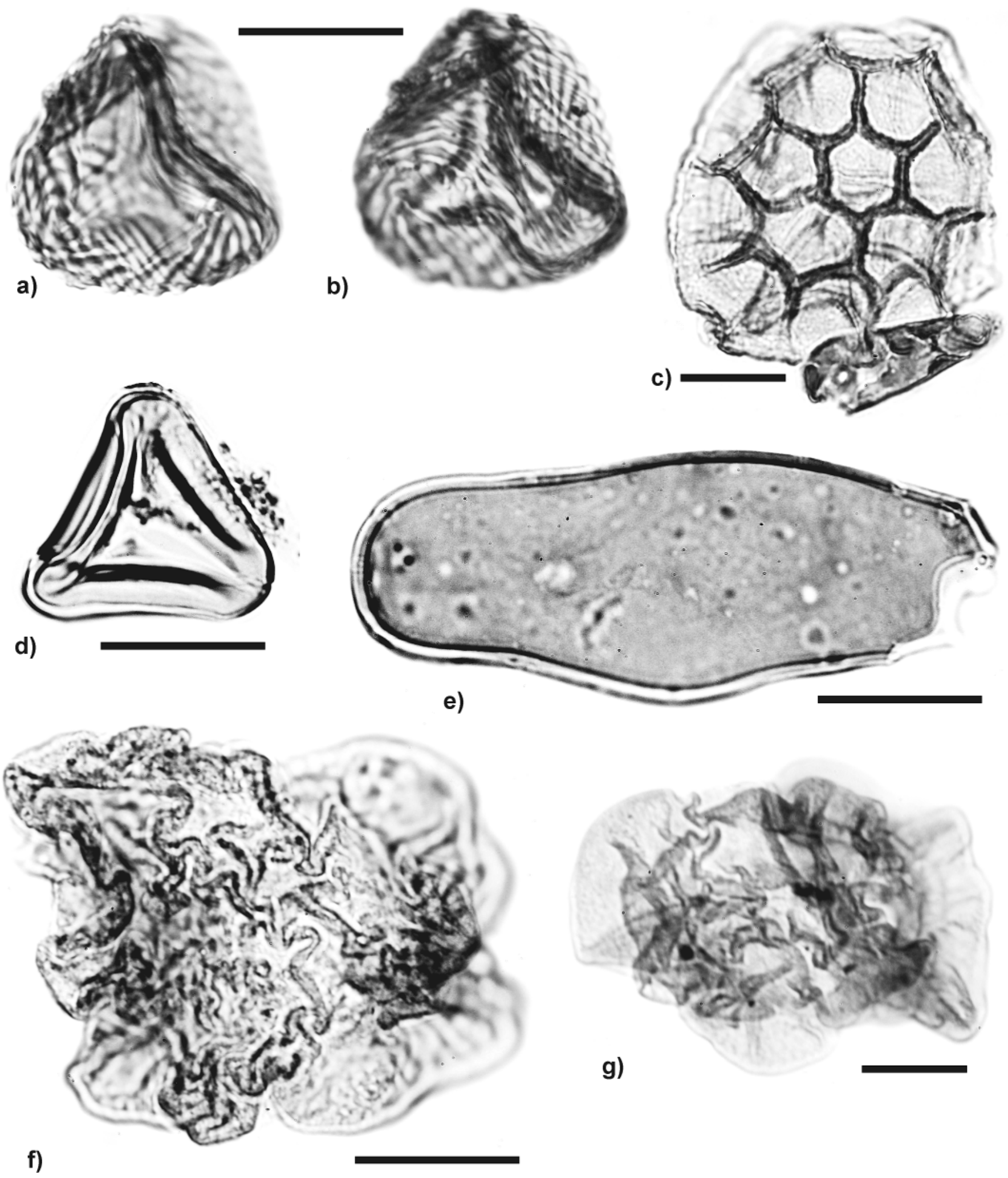

Fig. 3 Palynomorphs. a-b) Cicatricosisporites sp. Slide P37974-01, co-ordinates 16.8x100.3 (England Finder Q43/4). a) Proximal surface of specimen in proximal view. b) Distal surface of specimen in proximal view. c) Zlivisporis sp. Slide P37213-02, co-ordinates 19.8x99.9 (England Finder T43/3). d) Concavisporites toralis. Slide P37213-01, co-ordinates 15.8x96.9 (England Finder P40/0). e) Algal or fungal body. Slide P37974-01, co-ordinates 15.0x96.2 (England Finder O39/0). f-g). Rugubivesiculites reductus. f) Slide P37974-01, co-ordinates 19.7x106.2 (England Finder T49/4). g) Slide P37974-01, co-ordinates 13.2x91.6 (England Finder M34/4). All scale bars $20 \mu \mathrm{m}$. 

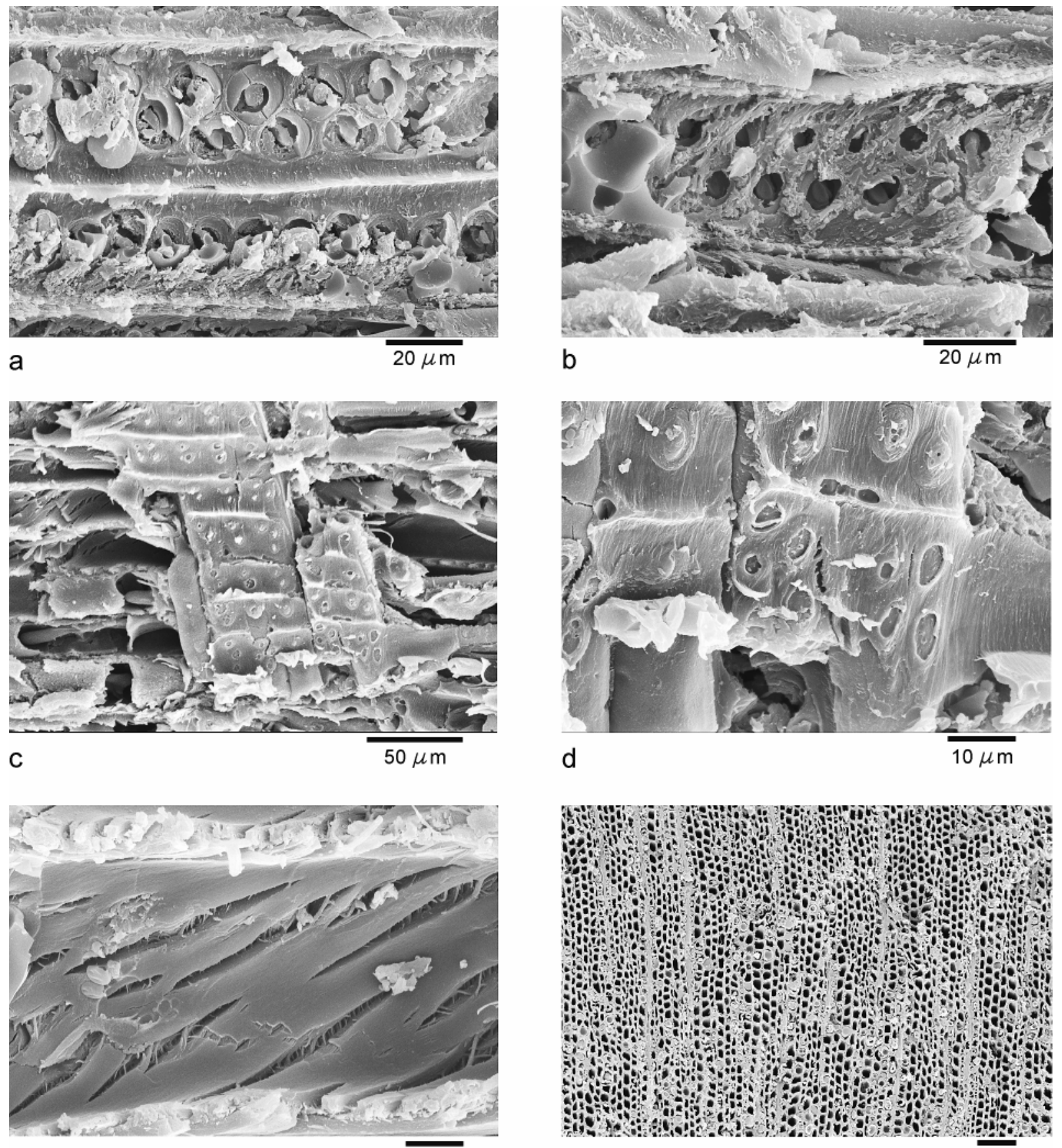

Fig. 4 Araucarioxylon cf. pseudoparenchymatosum, all SEM micrographs. a) Biseriate, alternate, bordered tracheid pits, RLS. b) Bordered tracheid pits showing cellular degradation, RLS. c) 1-4 araucarioid cross-field pitting, RLS. d) Close-up of araucarioid cross-field pits, RLS. e) Checking on longitudinal tracheids walls, TLS. f) Absence of distinct growth rings, TS.

\section{PALEOCLIMATE}

The absence of true growth rings in the araucarian wood implies growth under a humid subtropical climate characterized by high year-round temperatures (Creber 1977). However, weakly developed growth zones and checking features suggest a slight seasonality in rainfall (Schweingruber 1992; Jones 1993), an interpretation supported by charcoal in the Cretaceous lignites of Nova Scotia, if coeval (Stea and Pullan 2001). Similar palaeoclimatic conditions are suggested by the predominance of silica sand and kaolin clay in the Vinegar Hill deposit. Both lithologies represent the products of paleoweathering under warm, humid climates and, in the modern world, significant kaolin accumulations are restricted to tropical and subtropical regions (Leeder 1999).

Collectively, these data support a Cretaceous age for the Vinegar Hill deposit because the results of global paleoclimate reconstructions (which integrate paleobotanical and sedimentological information with computer modeling) suggest that eastern Canada was subject to a humid subtropical 
climate during Cretaceous time (Valdes et al. 1996; Paleomap 2000). During the Jurassic time the regional paleoclimate was arid subtropical while during Tertiary times it was temperate (Paleomap 2000).

\section{DISCUSSION AND CONCLUSIONS}

The Vinegar Hill quartz (silica) sand deposit overlies Carboniferous rocks and underlies glacial till deposits. Its similarity in lithology and setting to confirmed Cretaceous deposits in Nova Scotia has previously led to speculation of its Cretaceous age, but direct evidence has been previously unavailable. A microscopic analysis of the wood sample found at Vinegar Hill suggests a Mesozoic-Early Tertiary age, and the palynomorphs, although sparse, specifically confirm a Cretaceous date. The presence of Rugubivesiculites, the absence of angiosperm pollen and comparison with the Nova Scotia deposits suggest a late Early Cretaceous, probably Albian, age. Although the sedimentology of the Vinegar Hill deposit is beyond the scope of this study, general facies characteristics suggest a fluvial environment, and this interpretation is supported by the occurrence of only terrestrial fossils in the deposit.

In terms of stratigraphic nomenclature, given its similarity to the deposits of essentially identical age in Nova Scotia, the Vinegar Hill deposit should probably be referred to the Chaswood Formation (formally defined by Stea and Pullan 2001) rather than the "Vinegar Hill Formation" (New Brunswick Department of Natural Resources and Energy 2000).

The Vinegar Hill deposit is so far the only known example of its kind in New Brunswick, but given its economic significance and scientific interest, a search for similar basins in the province would be worthwhile. In their paper on the Nova Scotia Cretaceous basins, Stea and Pullan (2001) concluded that such deposits "... are undoubtedly more widespread throughout the drift-covered Carboniferous and Triassic basins of Nova Scotia." They noted that the best potential for such basins would be on the down-glacier side of horst blocks, where the deposits would have been relatively protected from glacial erosion. The setting of Vinegar Hill deposit (Fig. 1) fits this prediction, and there may be good potential for similar deposits in parallel settings elsewhere in New Brunswick.

\section{ACKNOWLEDGEMENTS}

We thank Dennis Braman, John Calder, Les Fyffe, Andrew MacRae, David Piper, John Shimeld and Ralph Stea for helpful suggestions for improvements to the manuscript. We express our sincere gratitude to Robert Pickett (President), Hazen Cummings and Vince Cummings of Atlantic Silica Inc. for their assistance and co-operation during the course of this study. We also thank Bill MacMillan of the Geological Suvery of Canada (Atlantic) for preparing the text-figures and to Bill and Rhonda Doiron (New Brunswick Department of Natural Resources and Energy) for other technical assistance. The contribution of HJFL was carried out largely during the tenure of a Killam Fellowship at Dalhousie University. This is Geological Survey of Canada Contribution no. 2002167.

\section{REFERENCES}

Atlantic Geoscience Society. 2001. The Last Billion Years: a Geological History of the Maritime Provinces of Canada. Atlantic Geoscience Society and Nimbus, Halifax, Canada, $212 \mathrm{p}$.

Barss, M.S., \& Williams, G.L. 1973. Palynology and nannofossil processing techniques. Geological Survey of Canada, Paper 73-26, 25 p.

BELT, E.S. 1965. Stratigraphy and paleogeography of Mabou Group and related Middle Carboniferous facies, Nova Scotia, Canada. Geological Society of America Bulletin, 76, pp. 777-802.

Braman, D.R. 2001. Terrestrial palynomorphs of the upper Santonian-lowest Campanian Milk River Formation, southern Alberta, Canada. Palynology, 25, pp. 57-107.

Creber, G.T. 1977. Tree-rings: a natural data storage system. Biological Reviews, 52, pp. 349-383.

EIsNoR, K. 2002. Palynology of the Lower Cretaceous Chaswood Formation, Elmsvale Basin and Shubenacadie Outlier, Nova Scotia. B.Sc. Thesis, Dalhousie University, Halifax, Nova Scotia, Canada, $114 \mathrm{p}$.

ENRIGHT, N.J., \& Hill, R.S. (editors). 1995. Ecology of the Southern Conifers. Melbourne Univ. Press, Melbourne, Australia, $245 \mathrm{p}$.

Falcon-Lang, H.J., \& Cantrill, D.J. 2001. Gymnosperm woods from the Cretaceous (mid-Aptian) Cerro Negro Formation, Byers Peninsula, Livingston Island, Antarctica: the arborescent vegetation of a volcanic arc. Cretaceous Research, 22, pp. 277-293.

Gothan, W. 1908. Die fossilen Hölzer von der Seymour und Snow Hill Insel. Wissenschaftliche Ergebnisse der Schwedischen Südpolar-Expedition 1901-1903, 3, pp. 1-33.

Greguss, P. 1972. Xylotomy of the Living Conifers. Akademia Kiado, Budapest, Hungary, 172 p.

Jones, T.P. 1993. New morphological and chemical evidence for a wildfire origin for fusain from comparisons with modern charcoal. Special Papers in Palaeontology, 49, pp. 113-123.

KRAÜSEL, R. 1925. Beiträge zur Kenntnis der fossilien Flora Südamerikas. I. Fossile Hölzer aus Patagonien und benachbarten Gebieten. Arkiv für Botanik, 19, pp. 1-36.

LEEDER, M.R. 1999. Sedimentology and sedimentary basins: from turbulence to tectonics. Blackwell, Oxford, U.K., 592 p.

Leschiк, G. 1955. Die Keuperflora von Neuewelt bei Basel. II. Die Iso- und Mikrosporen. Schweizerische Paläontologische Abhandlungen, 72, pp. 1-70, pl.1-10.

Lockhart, A.W. 1983. A.W. Lockhart Sussex silica and 
aggregate project, Sussex, New Brunswick, Canada. New Brunswick Department of Natural Resources and Energy Division, Assessment File 472918. (Unpublished report.)

Lockhart, A.W. 1984. A.W. Lockhart Sussex silica and aggregate project, Sussex, New Brunswick, Canada, N.T.S. 21-H-12-W. Assessment work report two. New Brunswick Department of Natural Resources and Energy, Minerals and Energy Division, Assessment File 473023. (Unpublished report.)

Lockhart, A.W. 1988. Sussex Silica Inc. Lockhart mine, Sussex, N.B., Canada, NTS 21-H-12-E. New Brunswick Department of Natural Resources and Energy, Minerals and Energy Division, Assessment File 473614. (Unpublished report.)

McLeod, M.J., Johnson, S.C., \& Ruitenberg, A.A. 1994. Geological map of southeastern New Brunswick. New Brunswick Department of Natural Resources and Energy Division, Map NR-6.

Mtchedlishvili, N.D., \& SAmoilovitch, S.R. 1960. New species of angiosperms. In New Species of Plants and Invertebrates of the U.S.S.R., Volume 1, p.127-134; VSEGEI, Government Technical Geology Publishers, Moscow, U.S.S.R. (In Russian.)

New Brunswick Department of Natural Resources AND ENERGY. 2000. Bedrock geology of New Brunswick Scale 1:500 000. New Brunswick Department of Natural Resources and Energy, Minerals and Energy Division, Map NR-1 (2000 edition).

NikLAs, K.J. 1994. Predicting the height of fossil plant remains: an allometric approach to an old problem. American Journal of Botany, 81, pp. 1235-1243.

NiLsson, T. 1958. Über das Vorkommen eines mesozoischen Sapropelgesteins in Schonen. Lunds Universitets Årsskrift, Ny Följd, Avd.2, 54, no.10, pp. 1-112, pl. 1-8.

Pacltová, B. 1961. On some plant microfossils from fresh-water sediments of the Upper Cretaceous (Senonian) in the south-Bohemian basins. Part I. Sbornik Ustředniho Ustavu Geologickeho, 26 (1959, Oddil Paleontologicky) pp. 47-102. (In Czech with English summary.)

Paleomar 2000. http://www.cscotese.com/default.htm

PIERCE, R.L. 1961. Lower Upper Cretaceous plant microfossils from Minnesota. Minnesota Geological Survey, Bulletin 42, pp. 1-86, pl. 1-3.

Рососк, S.A.J. 1962. Microfloral analysis and age determination of strata at the Jurassic-Cretaceous boundary in the western Canada plains. Palaeontographica, Abteilung B, 111, pp.1-95, pl.1-15.

Ротonié, R., \& Gelletich, J. 1933. Über Pteridophyten-Sporen einer eozänen Braunkohle aus Dorog in Ungarn. Sitzungsberichte der Gesellschaft, Naturforschungs Freunde zu Berlin, 1932, pp. 517-528, 2 pl.
St. Peter, C. 1995. Upper Devonian/Carboniferous bedrock geology of Wards Creek area (parts of NTS $21 \mathrm{H} / 11,12$ ). New Brunswick Department of Natural Resources and Energy, Minerals and Energy Division, Plate 95-10B.

St. Peter, C. 2001. Petroleum geology in the Carboniferous of southeastern New Brunswick. In $93^{\text {rd }}$ Annual Meeting New England Intercollegiate Geological Conference: Guidebook to Field Trips in New Brunswick and Western Maine. Edited by R. Pickerill and D. Lentz, pp. A4-1 - A4-30.

SCHWEINGRUBER, F.H. 1992. Annual growth rings and growth zones in woody plants in southern Australia. International Association of Wood Anatomists' Bulletin, 13, pp. 359379.

Stea, R.R., \& Pullan, S.E. 2001. Hidden Cretaceous basins in Nova Scotia. Canadian Journal of Earth Sciences, 38, pp. 1335-1354.

Stevenson, I.M. 1959. Shubenacadie and Kennetcook map areas, Colchester, Hants and Halifax counties, Nova Scotia. Geological Survey of Canada, Memoir 302, 88 p.

Valdes, P. J., Sellwood, B.W., \& Price, G. D. 1996. Evaluating concepts of Cretaceous equability. Palaeoclimates 2, pp. 139-158.

Venugopal, D.V. 1994. 3B. Geology and development of the Cassidy Lake silica deposit. In 30th Forum on the Geology of Industrial Minerals, Guide Book, May 1994, Fredericton and Halifax, Canada. Field trip \# 3, pp. 10-22;

Venugopal, D.V. 1999. Characterization of clay from the Cassidy Lake silica deposit, southern New Brunswick. New Brunswick Department of Natural Resources and Energy Division, Open File 99-13, 43 p.

Editorial responsibility: Ron K. Pickerill

\section{APPENDIX 1 TAXONOMIC NAMES MENTIONED IN THE TEXT}

Araucarioxylon cf. pseudoparenchymatosum (Gothan 1908) Kraüsel 1925

Cicatricosisporites Potonié and Gelletich 1933

Concavisporites toralis (Leschik 1955) Nilsson 1958

Rouseisporites Pocock 1962

Rugubivesiculites Pierce 1961

Rugubivesiculites reductus Pierce 1961

Triporoletes Mtchedlishvili in Mtchedlishvili and Samoilovitch 1960

Zlivisporis Pacltová 1961 